\title{
Investigasi Kemampuan Mahasiswa dalam Menulis Esai Ilmiah pada Mata Kuliah Composition and Essay Writing
}

\author{
M. Fadhly Farhy Abbas, Herdi \\ Universitas Lancang Kuning \\ fadhly@unilak.ac.id
}

\begin{abstract}
Abstrak: Penelitian ini didasari dengan adanya kebutuhan untuk menginvestigasi kemampuan mahasiswa dalam menulis esai ilmiah. Hal ini diperlukan sebagai bahan evaluasi mata kuliah Composition and Essay Writing. Penelitian ini bertujuan untuk menganalisis kemampuan mahasiswa dalam menulis esai ilmiah. Metode penelitian yang digunakan adalah metode kuantitatif dengan rancangan penelitian deskriptif kuantitatif. Sampel dari penelitian ini adalah mahasiswa semester 4 pada Program Studi Pendidikan Bahasa Inggris, Fakultas Keguruan dan Ilmu Pendidikan (FKIP) Universitas Lancang Kuning (UNILAK) Tahun Akademik 2020/2021 yang berjumlah sebanyak 56 orang. Instrumen yang digunakan untuk mengumpulkan data adalah tes menulis esai ilmiah dan wawancara. Setelah data dikumpulkan, peneliti menganalisis hasil tes dengan menggunakan rubrik penilaian serta tabel kategori nilai. Kemudian, peneliti menjelaskan data yang diperoleh dari hasil wawancara secara deskriptif. Setelah data dikumpulkan, ditemukan bahwa kemampuan mahasiswa dalam menulis esai ilmiah pada mata kuliah Composition and Essay Writing dikategorikan ke dalam kemampuan yang baik dengan nilai rata-rata 81 . Kemudian, dari hasil wawancara ditemukan informasi bahwa mahasiswa cukup memahami dan menguasai keahlian menulis. Hal ini karena mahasiswa sudah melalui mata kuliah menulis sebelumnya, yaitu Paragraph Writing. Mahasiswa merasa cukup mampu dalam hal mengemukakan thesis statement, mampu menguasai konsep unity, coherence, cohesion, serta logical order dalam penulisan esai ilmiah. Selain itu, mahasiswa juga merasa senang dan aktif ketika diminta untuk menemukan ide atau inspirasi untuk mereka tuliskan menjadi sebuah esai ilmiah. Sebagai kesimpulan, kemampuan mahasiswa dalam menulis esai ilmiah pada mata kuliah Composition and Essay Writing adalah merupakan kemampuan menulis yang baik.

Kata kunci: Kemampuan Menulis, Composition and Essay Writing, Esai Ilmiah
\end{abstract}

\begin{abstract}
This research is based on the need to investigate students' ability to write scientific essays. This is needed as an evaluation material for the Composition and Essay Writing course. This study aims to analyze the ability of students in writing scientific essays. The research method used was a quantitative method with a quantitative descriptive research design. The sample of this research was the $4^{\text {th }}$ semester students of the English Education Department, Faculty of Teacher Training and Education (FKIP) Universitas Lancang Kuning in Academic Year 2020/2021, totaling 56 people. The instruments used to collect data were scientific essay writing tests and interviews. After the data was collected, the researcher analyzed the test results by using a scoring rubric and the score category table. Then, the researcher explained the data obtained from the interviews descriptively. After the data was collected, it was found that the students' ability in writing scientific essays in the Composition and Essay Writing courses was categorized into good ability with an average score of 81 .
\end{abstract}


Then, from the interviews, the information was found that the students understood and mastered the writing skills. This was because the students have learned the previous writing course, namely Paragraph Writing. The students felt quite capable in terms of presenting a thesis statement, able to master the concepts of unity, coherence, cohesion, and logical order in writing scientific essays. In addition, the students also felt happy and active when they were asked to find ideas or inspiration to be written into a scientific essay. In conclusion, the ability of the students to write scientific essays in the Composition and Essay Writing courses is a good writing ability.

Keywords: Writing Skill, Composition and Essay Writing, Scientific Essays

\section{Pendahuluan}

Keahlian menulis (Writing skill) adalah salah satu keahlian yang harus dimiliki dan dikuasai oleh setiap mahasiswa pada Program Studi Pendidikan Bahasa Inggris Fakultas Keguruan dan Ilmu Pendidikan (FKIP) Universitas Lancang Kuning (UNILAK). Salah satu keahlian menulis yang harus dimiliki oleh mahasiswa tersebut adalah menulis sebuah paragraf dan esai ke dalam bahasa Inggris dengan baik dan benar. Semakin baik kemampuan mahasiswa dalam menulis sebuah paragraf dan esai, maka akan semakin baik pula kemampuan mereka dalam menulis bentuk tulisan lainnya seperti tulisan-tulisan ilmiah berupa esai ilmiah (scientific writing) seperti esai argumentatif, tulisan akademik (academic writing), atau jenis-jenis teks (Text types) dalam bahasa Inggris.

Dalam menulis, ada dua aspek yang harus diperhatikan oleh penulis. Pertama, writing process (proses menulis) seperti: prewriting, drafting, revising, editing, dan publishing (Fachrurrazy, 2011:90). Kedua, micro dan macro skills dalam menulis seperti kemampuan dalam menggunakan pilihan kata yang tepat, tata bahasa, dan mekanisme penulisan seperti: penggunaan huruf besar, ejaan, dan tanda baca (Brown, 2007:90). Dengan memperhatikan aspek-aspek di atas, kegiatan menulis akan menjadi mudah dan dapat membantu meningkatkan kemampuan menulis seseorang.

Selain aspek-aspek di atas, ada dua unsur yang harus ada dalam sebuah paragraf dan esai. Dua unsur tersebut adalah unity dan coherence. Oshima dan Hogue (2006:18) menyatakan bahwa unity adalah kesatuan ide dalam sebuah paragraf, sedangkan coherence adalah keterhubungan antara satu kalimat dengan kalimat berikutnya atau satu paragraf dengan paragraf lainnya. Jadi, sebuah paragraf atau esai dapat dikatakan baik apabila paragraf atau esai tersebut terdapat unsur unity dan coherence yang baik pula.

Dalam kegiatan menulis, ada beberapa bentuk tulisan yang bisa dihasilkan. Diantara contohnya adalah paragraf dan esai. Paragraf terdiri dari beberapa kalimat yang menjelaskan sebuah topik (Hornby:2010). Paragraf juga merupakan suatu kesatuan kalimat yang mengembangkan sebuah ide pokok. Dalam sebuah paragraf, terdapat 3 struktur atau susunan yang harus tertuang di dalamnya. 3 struktur paragraf tersebut adalah: kalimat topik (Topic sentence), kalimat pendukung (Supporting sentence), dan kalimat penutup (Concluding sentence) (Oshima dan Hogue, 2007:3-4). Jadi, paragraf yang baik adalah paragraf yang di dalamnya terdapat 3 struktur atau susunan paragraf tersebut. Sedangkan esai adalah kumpulan beberapa paragraf yang menjelaskan subjek atau ide tertentu (Hornby:2010). Paragraf dan esai yang baik harus memiliki dua unsur yaitu unity dan coherence. Oshima dan Hogue (2007:18) menyatakan bahwa unity adalah kesatuan ide dalam sebuah paragraf, sedangkan coherence adalah keterhubungan antara satu kalimat dengan kalimat berikutnya atau satu paragraf 
dengan paragraf lainnya. Jadi, sebuah paragraf atau esai dapat dikatakan baik apabila paragraf atau esai tersebut terdapat unsur unity dan coherence yang baik pula.

Seiring dengan penjelasan di atas, ada beberapa aspek yang harus diperhatikan dalam menulis sebuah paragraf dan esai. Aspek-aspek tersebut adalah: Content (Pengembangan topik), Organization (Penyusunan paragraf), Vocabulary (Penggunaan kosa kata), Grammar (Penggunaan tata bahasa), dan Mechanics (Mekanisme penulisan seperti: penggunaan huruf besar, tanda baca, dan ejaan) (Brown, 2007:90). Dengan memperhatikan aspek-aspek tersebut, paragraf dan esai yang ditulis akan menjadi baik hasilnya.

Sebagaimana yang telah dijelaskan sebelumnya bahwa esai adalah salah satu bentuk tulisan ilmiah yang dapat dihasilkan oleh penulis. Pada dasarnya, ada banyak bentuk esai yang dapat dituliskan oleh penulis, salah satu diantaranya adalah esai ilmiah berbentuk argumentatif. Esai argumentatif adalah sebuah tulisan ilmiah yang berisikan argumen, penjelasan, pembuktian, atau alasan. Umumnya, dalam Esai argumentatif terdapat ulasan obyektif atau informasi disertai contoh, analogi, dan sebab akibat (wikipedia.org), (Housden, 2008:18), (Leo, 2007:21). Selanjutnya, di dalam Esai argumentatif juga bisa berisikan argumen tentang pro (ide yang mendukung) dan kontra (ide yang bertentangan) terhadap isuisu atau topik-topik yang dibahas (www.buowl.boun.edu).

Selanjutnya, ada beberapa penelitian sebelumnya yang relevan dengan penelitian ini yang dapat digunakan sebagai rujukan. Penelitian tersebut adalah sebagai berikut. Pertama, Abbas dan Herdi (2017) meneliti tentang penerapan unity dan coherence pada esai ilmiah yang dilakukan oleh mahasiswa prodi pendidikan bahasa Inggris FKIP UNILAK. Hasil penelitian ini menunjukkan bahwa kemampuan mahasiswa dalam menerapkan dua unsur tersebut berada dalam kategori sedang atau menengah dengan nilai rata-rata 68.8. Kedua, Fajri (2016) melakukan penelitian tentang penggunaan unity, coherence, dan word usage dalam sebuah paragraf. Hasil penelitian tersebut menunjukkan bahwa siswa tidak mampu mengaplikasikan unity, coherence, dan word usage dengan baik dalam sebuah paragraf. Kesalahan umum yang terjadi dipengaruhi oleh bahasa ibu (mother tongue) dan kesulitan dalam belajar bahasa Inggris tersebut. Sehingga, dapat disimpulkan bahwa kesalahankesalahan yang terjadi disebabkan oleh adanya pengaruh atau faktor pembelajaran dan pemerolehan suatu bahasa. Ketiga, Penelitian oleh Fahim dan Rad (2012), yaitu tentang hubungan siswa yang memiliki pemikiran yang baik terhadap kemampuan menulis paragraf. Hasil penelitian mereka menunjukkan bahwa siswa yang memiliki pemikiran yang baik sangat berpengaruh terhadap kemampuan menulis paragraf. Jadi, semakin baik pola pemikiran seseorang terhadap menulis akan semakin baik pula kemampuan menulisnya. Keempat, Penelitian oleh Crosthwaite (2011), yaitu tentang pengaruh kolaborasi Cohesion dan Coherencedalam bahasa atau wacana tulisan dan lisan dengan menggunakan scaffold antara penutur bahasa Inggris asli dan pelajar korea yang menggunakan bahasa Inggris sebagai bahasa ke dua. Hasil penelitian tersebut menunjukkan bahwa penggunaan scaffold dapat membantu pelajar korea dalam menyampaikan suatu bahasa atau wacana tulisan maupun lisan dengan baik. Sehingga, unsur cohesion dan coherence dalam suatu wacana juga dapat diaplikasikan dengan baik. Kelima, Penelitian yang dilaksanakan oleh Gupta dan Woldemariam (2011). Penelitian tersebut berhubungan dengan pengaruh motivasi dan sikap terhadap strategi menulis. Dari penelitian tersebut, diperoleh hasil bahwa siswa yang memiliki motivasi tinggi dalam menulis dapat dilihat dari tingginya rasa suka terhadap menulis, percaya diri, kemampuan yang mendukung, dan sikap yang baik terhadap strategi menulis tersebut. Hal ini menunjukkan bahwa, untuk bisa menulis dengan baik, diperlukan motivasi dan rasa 
percaya diri yang tinggi, serta sikap dan pemikiran yang positif. Keenam, Penelitian oleh Ahmed (2010), yaitu tentang Cohesion dan Coherence dalam menulis esai. Dari hasil penelitian ini, dapat dilihat bahwa siswa memiliki kesulitan dalam menulis pembukaan paragraf, kalimat topik, dan kalimat penutup atau kesimpulan. Hal ini menunjukkan bahwa, dalam menulis sebuah paragraf perlu diperhatikan unsur dalam sebuah tulisan seperti Cohesion dan Coherence agar tulisan yang dihasilkan menjadi sebuah tulisan yang baik.

Seiring dengan pernyataan di atas, peneliti tertarik untuk melakukan sebuah penelitian guna menganalisis kemampuan mahasiswa dalam menulis esai ilmiah. Penelitian ini memberikan gambaran tentang kemampuan mahasiswa dalam dalam menulis esai ilmiah yang berikutnya dapat digunakan sebagai bahan evaluasi mata kuliah Composition and Essay Writing.

\section{Metode Penelitian}

Metode penelitian yang digunakan dalam penelitian ini adalah metode kuantitatif. Berdasarkan metode dan latar belakang penelitian ini, rancangan penelitian yang sesuai adalah rancangan penelitian deskriptif kuantitatif. Hal ini karena peneliti mengkalkulasikan, mengolah, dan menganalisis data yang dikumpulkan secara kuantitatif yaitu data olahan yang berupa angka, dan mendeskripsikan data tersebut secara deskriptif yaitu berupa penjelasan dalam bentuk pernyataan. Selanjutnya, tahapan penelitian ini adalah sebagai berikut. Pertama, peneliti menyiapkan lembar writing test dan panduan wawancara sebagai instrumen/alat untuk mengumpulkan data. Kedua, mahasiswa diminta untuk menuliskan sebuah esai ilmiah ke dalam bahasa Inggris pada lembar writing test dan menjawab pertanyaan pada sesi wawancara untuk mendukung data yang dikumpulkan melalui tes tersebut. Ketiga, peneliti memberikan penilaian dan analisis terhadap hasil tes dan wawancara tersebut. Keempat, peneliti menyimpulkan kemampuan mahasiswa dalam menulis esai ilmiah.

Penelitian in dilakukan di Program Studi Pendidikan Bahasa Inggris, Fakultas Keguruan dan Ilmu Pendidikan (FKIP), Universitas Lancang Kuning (UNILAK) yang terletak di Jl. Yos Sudarso KM. 08 Pekanbaru-Riau. Selanjutnya, yang menjadi partisipan dalam penelitian ini adalah mahasiswa semester 4 pada Program Studi Pendidikan Bahasa Inggris, FKIP-UNILAK Tahun Akademik 2020/2021 yang berjumlah sebanyak 56 orang. Pengumpulan data dilakukan dengan menggunakan instrumen penelitian seperti: writing test dan wawancara. Dalam penelitian ini, mahasiswa diminta untuk menuliskan esai ilmiah berdasarkan instruksi yang terdapat dalam lembar writing test. Kemudian, peneliti melakukan wawancara kepada mahasiswa untuk mendukung data yang diperoleh dari hasil tes. Setelah data dikumpulkan melalui instrumen penelitian yang sudah dijelaskan di atas, peneliti menilai dan menganalisis hasil tes mahasiswa dengan menggunakan rubrik penilaian dan tabel kategori skor dalam penulisan esai ilmiah (diadaptasikan dari Abbas, 2013:51 dan Abbas, 2015: 44-47). Rubrik penilaian tersebut mencakup seluruh aspek menulis seperti: Content, Organization, Vocabulary, Grammar, dan Mechanics. Selanjutnya, hasil wawancara dijelaskan dan dianalisis secara deskriptif. Selanjutnya, rubrik penilaian dan tabel kategori skor dalam penulisan esai ilmiah dapat dilihat sebagai berikut. 
Tabel 1. Rubrik Penilaian Penulisan Esai Ilmiah

\begin{tabular}{|c|c|c|c|}
\hline Aspects & Criteria & Scores & Categories \\
\hline Content: & - Thorough development of topic & 10 & Very Good \\
\hline Topic & - Relevant to topic but lacks detail & 9 & Good \\
\hline \multirow[t]{3}{*}{ development } & - Inadequate development of topic & 8 & Fair \\
\hline & - Does not show knowledge of topic & 7 & Poor \\
\hline & - Very good organization & 5 & Very Good \\
\hline Organization: & - Loosely organized but ideas stand out & 4 & Good \\
\hline \multirow[t]{3}{*}{$\begin{array}{l}\text { Paragraph } \\
\text { organization }\end{array}$} & $\begin{array}{l}\text { - Incoherent ideas and lacks logical } \\
\text { sequencing }\end{array}$ & 3 & Fair \\
\hline & $\begin{array}{l}\text { - Does not follow generic structures } \\
\text { correctly }\end{array}$ & 2 & Poor \\
\hline & $\begin{array}{l}\text { - Employ accurate and effective choice of } \\
\text { words/diction }\end{array}$ & 10 & Very Good \\
\hline Vocabulary: & - Employ accurate diction, but not effective & 9 & Good \\
\hline \multirow[t]{3}{*}{$\begin{array}{l}\text { Word } \\
\text { choice/diction }\end{array}$} & $\begin{array}{l}\text { - Employ lacks accuracy of diction, but } \\
\text { meaning not obscured }\end{array}$ & 8 & Fair \\
\hline & $\begin{array}{l}\text { - Errors in applying diction or word form, } \\
\text { and meaning obscured }\end{array}$ & 7 & Poor \\
\hline & $\begin{array}{l}\text { - Use correct grammar (tenses, pronouns, } \\
\text { subject-verb agreement, etc) }\end{array}$ & 10 & Very Good \\
\hline $\begin{array}{l}\text { Grammar: } \\
\text { Sentence }\end{array}$ & $\begin{array}{l}\text { - Several errors of tense, pronouns, subject- } \\
\text { verb agreement, etc, but meaning not } \\
\text { obscured }\end{array}$ & 9 & Good \\
\hline \multirow[t]{2}{*}{$\begin{array}{l}\text { Structure/ } \\
\text { construction }\end{array}$} & $\begin{array}{l}\text { - Major errors of tense, pronouns, subject- } \\
\text { verb agreement, etc, and meaning } \\
\text { obscured }\end{array}$ & 8 & Fair \\
\hline & $\begin{array}{l}\text { - No mastery of sentence construction and } \\
\text { dominated by errors }\end{array}$ & 7 & Poor \\
\hline \multirow{4}{*}{$\begin{array}{l}\text { Mechanics: } \\
\text { Spelling, } \\
\text { punctuation, and } \\
\text { capitalization. }\end{array}$} & - Very little errors of mechanics & 5 & Very Good \\
\hline & $\begin{array}{l}\text { - Few errors of mechanics, but meaning not } \\
\text { obscured }\end{array}$ & 4 & Good \\
\hline & $\begin{array}{l}\text { - Many errors of mechanics, and meaning } \\
\text { obscured }\end{array}$ & 3 & Fair \\
\hline & - Dominated by errors of mechanics & 2 & Poor \\
\hline
\end{tabular}

$\begin{aligned} \text { Maximum score } & =40 \\ \text { Students' score } & =\frac{\text { Obtained score }}{\text { Maximum Score }} \times 100=\text { Final Score } \\ \text { Example } & =\frac{40}{40} \times 100=100\end{aligned}$


Tabel 2. Kategori Nilai Akhir

Range of Final Scores Categories

\begin{tabular}{cc}
\hline $86-100$ & Very Good \\
$71-85$ & Good \\
$56-70$ & Fair \\
$10-55$ & Poor \\
\hline (diadaptasikan dari Abbas, 2015: 44-47)
\end{tabular}

\section{Hasil dan Pembahasan}

Berdasarkan data yang dikumpulkan melalui tes menulis, ditemukan bahwa nilai ratarata mahasiswa adalah 81 . Nilai rata-rata ini dikategorikan ke dalam nilai dengan kemampuan menulis yang baik (good). Dari rata-rata tersebut, dapat dirincikan bahwa nilai yang diperoleh mahasiswa adalah berkisar antara 70 sampai dengan 97.5, namun ada juga yang memperoleh nilai di bawah itu yaitu 32 sampai dengan 65 . Berdasarkan kategori nilai akhir, nilai perolehan yang berkisar antara 71 sampai dengan 85 dikategorikan ke dalam kemampuan yang baik (good). Selanjutnya, nilai perolehan $86 \mathrm{ke}$ atas dikategorikan ke dalam kemampuan yang sangat baik (very good). Secara individu, dapat dijelaskan bahwa mahasiswa yang memperoleh nilai 97.5 adalah sebanyak 1 orang, nilai 95 diperoleh sebanyak 1 orang, nilai 92.5 diperoleh sebanyak 3 orang, nilai 90 diperoleh sebanyak 7 orang, nilai 87.5 diperoleh sebanyak 12 orang, nilai 85 diperoleh sebanyak 6 orang, nilai 82.5 diperoleh sebanyak 7 orang, nilai 80 diperoleh sebanyak 5 orang, nilai 77.5 diperoleh sebanyak 6 orang, nilai 75 diperoleh sebanyak 1 orang, nilai 72.5 diperoleh sebanyak 1 orang, nilai 70 diperoleh sebanyak 2 orang, nilai 65 diperoleh sebanyak 1 orang, nilai 62.5 diperoleh sebanyak 1 orang, nilai 37.5 diperoleh sebanyak 1 orang, dan nilai 32.5 diperoleh sebanyak 1 orang. Selanjutnya, rincian perolehan nilai menulis ini, dapat dilihat pada Tabel 2 berikut.

Tabel 2. Rincian Perolehan Nilai Menulis

\begin{tabular}{cccc} 
No & Score & Category & Number of Students \\
\hline 1 & 97.5 & Very Good & 1 \\
2 & 95 & Very Good & 1 \\
3 & 92.5 & Very Good & 3 \\
4 & 90 & Very Good & 7 \\
5 & 87.5 & Very Good & 12 \\
6 & 85 & Good & 6 \\
7 & 82.5 & Good & 7 \\
8 & 80 & Good & 5 \\
9 & 77.5 & Good & 6 \\
10 & 75 & Good & 1
\end{tabular}




\begin{tabular}{cccc}
11 & 72.5 & Good & 1 \\
12 & 70 & Fair & 2 \\
13 & 65 & Fair & 1 \\
14 & 62.5 & Fair & 1 \\
15 & 37.5 & Poor & 1 \\
16 & 32.5 & Poor & 1 \\
\hline \multicolumn{7}{c}{ Total of Students } \\
\hline
\end{tabular}

Seiring dengan rincian perolehan nilai menulis mahasiswa yang disajikan pada Tabel 2 di atas, frekuensi perolehan kategori nilai menulis yang diperoleh mahasiswa juga dapat dilihat pada Gambar 1 berikut ini.

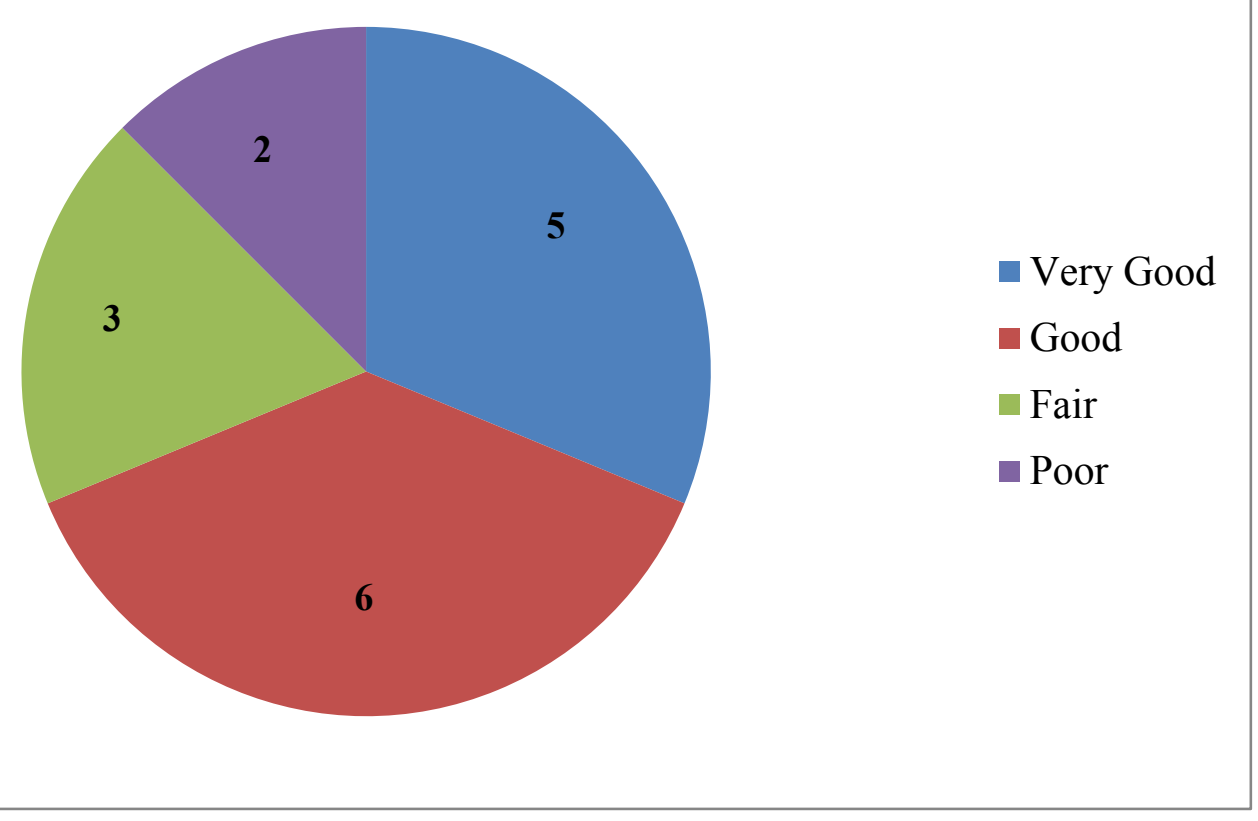

\section{Gambar 1. Frekuensi Perolehan Kategori Nilai Menulis Mahasiswa}

Berdasarkan informasi yang tersaji pada Gambar 1 di atas, dapat dilihat bahwa ada 4 kategori nilai menulis yang diperoleh mahasiswa yaitu kategori very good, good, fair, dan poor. Kategori nilai tersebut didukung oleh frekuensi seberapa sering kategori nilai tersebut diperoleh mahasiswa. Berdasarkan data pada Gambar 2, kategori nilai very good diperoleh sebanyak 5 kali, kategori nilai good diperoleh sebanyak 6 kali, kategori nilai fair diperoleh sebanyak 3 kali, kategori nilai poor diperoleh sebanyak 2 kali. Berdasarkan frekuensi tersebut, kategori nilai good merupakan kategori nilai yang paling sering dan paling banyak diperoleh mahasiswa dengan nilai rata-rata 81 kategori good. Dengan kata lain, dapat dinyatakan bahwa kemampuan mahasiswa dalam menulis esai ilmiah berada dalam kemampuan yang baik. 
Sebagai tambahan, serta berdasarkan hasil wawancara dengan mahasiswa, diperoleh informasi tambahan bahwa secara keseluruhan kemampuan mahasiswa dalam menulis esai ilmiah terbilang sangat baik. Hal ini karena mahasiswa sudah menjalani mata kuliah writing sebelumnya yaitu Paragraph Writing, ditambah dengan pemahaman mahasiswa tentang tips menulis esai tersebut sehingga dapat memudahkan mereka dalam menulis esai ilmiah. Selain itu, mahasiswa juga cukup mampu dan memahami cara mengembangkan ide, mengorganisasikan ide ke dalam paragraf, menggunakan pilihan kata dan tata bahasa yang tepat, serta mengaplikasikan mekanisme penulisan yang tepat seperti penggunaan tanda baca, huruf kapital, dan ejaan dalam sebuah esai. Berdasarkan hasil tes dan wawancara tersebut di atas, dapat dinyatakan bahwa secara keseluruhan kemampuan mahasiswa dalam menulis esai ilmiah dikategorikan ke dalam kemampuan yang sangat baik.

Seiring dengan penjelasan di atas, serta berdasarkan hasil temuan dari penelitian ini, dapat dijelaskan dan dibahas kembali bahwa baiknya kemampuan mahasiswa dalam menulis esai ilmiah adalah dipengaruhi oleh baiknya kemampuan mahasiswa tersebut dalam mengaplikasikan teori atau unsur-unsur menulis seperti Unity, Coherence, Cohesion, dan Word Usage. Hal ini sejalan dengan penelitian yang dilakukan oleh Abbas dan Herdi (2017), Fajri (2016), Crosthwaite (2011), dan Ahmed (2010). Berdasarkan hasil penelitian mereka, ditemukan bahwa baiknya kemampuan menulis seseorang dipengaruhi oleh baiknya kemampuan seorang tersebut dalam mengaplikasikan unsur menulis seperti Unity, Coherence, dan lain sebagainya seperti yang sudah dijelaskan sebelumnya.

Meskipun kemampuan menulis mahasiswa dalam menulis esai ilmiah terbilang sangat baik, ada dua hal yang menjadi kelemahan atau kekurangan mahasiswa tersebut. Pertama, kurang meluangkan waktu untuk latihan menulis. Kedua, tidak semua mahasiswa memahami dan menguasai tips menulis esai dengan baik. Berdasarkan hasil analisis ini, perlu dicarikan atau dibuatkan semacam usaha untuk mengatasi kelemahan atau kekurangan mahasiswa dalam menulis esai ilmiah tersebut.

\section{Kesimpulan dan Saran}

Berdasarkan hasil temuan dan pembahasan dalam penelitian ini, dapat disimpulkan bahwa secara keseluruhan kemampuan mahasiswa dalam menulis esai ilmiah digolongkan ke dalam kemampuan yang baik. Hal ini ditunjukkan oleh nilai rata-rata mahasiswa yaitu 81 . Hasil tes tersebut didukung oleh hasil wawancara yang intinya mahasiswa menyatakan bahwa mereka mampu menulis esai dengan baik karena mahasiswa tersebut cukup mampu dan memahami cara menulis esai tersebut.

Sejalan dengan kesimpulan di atas, ada beberapa saran yang dapat dikemukakan sebagai berikut. Pertama, mahasiswa yang menjadi partisipan dalam penelitian ini disarankan untuk sering berlatih dan menguasai lagi tips menulis esai dengan baik, sehingga kemampuan mahasiswa dalam menulis esai dapat dipertahankan atau ditingkatkan menjadi jauh lebih baik lagi. Kedua, dosen yang mengampu mata kuliah Writing disarankan untuk memberikan bimbingan dan latihan yang lebih intens lagi kepada mahasiswa, khususnya yang nilainya masih jauh dari kategori baik (71), agar kemampuan mahasiswa tersebut dapat ditingkatkan lebih baik lagi. Ketiga, peneliti selanjutnya yang ingin melakukan penelitian yang berkaitan dengan Writing dapat menjadikan hasil penelitian ini sebagai bahan rujukan dan setiap teori yang digunakan dalam penelitian ini dapat pula digunakan sebagai rujukan untuk melakukan penelitian lanjutan dengan metode dan rancangan penelitian yang berbeda, seperti rancangan Penelitian Tindakan Kelas (PTK) atau penelitian Eksperimen. 


\section{Daftar Pustaka}

Abbas, M. Fadhly Farhy. 2013. Applying Collaborative Writing Process Strategy to Improve Students' Ability in Writing a Narrative Text. Tesis Tidak Dipublikasikan. Malang: Universitas Negeri Malang Press.

Abbas, M. Fadhly Farhy. 2015. Analysis of Students' Ability in Writing a Research Proposal. ELT-Lectura Journal; Vol. 2, No. 2; 44-47.

Abbas, M. Fadhly Farhy dan Herdi. 2017. Analysis of Unity and Coherence in Writing Scientific Essay at the Fifth Semester Students of English Department FKIP UNILAK 2016/2017 Academic Year. J-SHMIC: Journal of English for Academic, Vol.4/No.1/2017.

Ahmed, Abdel Hamid. 2010. Students' Problems with Cohesion and Coherence in EFL Essay Writing in Egypt: Different Perspectives. Literacy Information and Computer Education Journal (LICEJ), Volume 1, Issue 4, 211-221.

Arikunto, Suharsimi. 2010. Prosedur Penelitian Suatu Pendekatan Praktik.Edisi Revisi. Jakarta: Rineka Cipta.

Brown, H.D. 2007. Teaching by Principles; An Interactive Approach to Language Pedagogy (3rd Edition). White Plains, New York: Pearson Education.

Crosthwaite, Peter. 2011. The Effect of Collaboration on the Cohesion and Coherence of L2 Narrative Discourse between English NS and Korean L2 English Users. Asian EFL Journal, Volume 13, Issue 4, 135-166.

Fachrurrazy. 2011. Teaching English as a Foreign Language for Teachers in Indonesia. Malang: Universitas Negeri Malang Press.

Fahim, Mansoor \& Rad, S.K. 2012. The Relationship between Self-Esteem and Paragraph Writing of Iranian EFL Learners. Scientific Research Journal ofPsychology, Volume. 3 No. 1, 24-29.

Fajri, Nurul. 2016. Assessing unity, coherence and word usage in students' writing. English Education Journal (EEJ), 7(1), 102-116.

Gupta, Deepti dan Woldemariam G.S. 2011. The Influence of Motivation and Attitude on Writing Strategy Use of Undergraduate EFL Students: Quantitative and Qualitative Perspectives. Asian EFL Journal, Volume 13, Issue 2, 34-89.

Hornby. A.S. 2010. Oxford Advanced Learner's Dictionary( $8^{\text {th }}$ edition). Cambridge: Longman. 
Housden, Elli. 2008. Senior Text Types: A Writing Guide for Students. Queensland: FarrBooks.

Leo, S. 2007. English for Academic Purpose: Essay Writing. Yogyakarta: C.V. Andi Offset.

Oshima, Alice \& Hogue, Ann. 2006. Writing Academic English (4 ${ }^{\text {th }}$ edition). New York: Pearson Longman.

Oshima, Alice \& Hogue, Ann. 2007. Introduction to Academic Writing. New York: Pearson Longman. 